\title{
COMPARISON OF CARPASTRETCH® WITH SPLINT IN NON-SURGICAL TREATMENT OF CARPAL TUNNEL SYNDROME: A RANDOMIZED OPEN LABEL STUDY
}

\author{
Vijay Anandrao Malshikare ${ }^{1}$, Sanjay Mukund Desai ${ }^{2}$, Anil Shridhar Arekar ${ }^{3}$, Neelambari Abhay Bhosale ${ }^{3}$, Shital Ravindra \\ Bonde $^{3}$, Mansi Abhishek Awadhani ${ }^{3}$ \\ Correspondence: vijay0077877@ rediffmail.com \\ ${ }^{I}$ Wrist and Hand Surgery, Jehangir Hospital, Maharashtra, India. \\ ${ }^{2}$ Deenanath Mangeshkar Hospital \& Research Centre, Maharashtra, India. \\ ${ }^{3}$ Jehangir Clinical Development Centre Pvt. Ltd., Jehangir Hospital Premises, Maharashtra, India.
}

\section{Article History:}

Received: May 22, 2018

Accepted: August 3, 2018

Published: January 1, 2019

\section{Cite this as:}

Malshikare VA, Desai SM, Arekar AS, Bhosale NA, Bonde SR, Awadhani MA. Comparison of carpastretch ${ }^{\circledR}$ with splint in nonsurgical treatment of carpal tunnel syndrome: a randomized open label study. Malang

Neurology Journal; 2019.5:1420. DOI:

http://dx.doi.org/10.21776/ub.mnj .2019.005.01.3

\section{ABSTRACT}

Background: The present study was conducted with an aim to compare the efficacy and safety of CarpaStretch $^{\circledR}$ relative to wrist splinting in patients with CTS.

Objective: To examine the effect of using CarpaStretch ${ }^{\circledR}$, a novel dynamic splint for the treatment of Carpal Tunnel Syndrome.

Methods: The efficacy and safety of CarpaStretch ${ }^{\circledR}$ was compared with conventional splints in a prospective 6-month trial with a follow-up at 12 months. 30 subjects with confirmed Carpal Tunnel Syndrome were enrolled in each group. Nerve conduction tests, wrist MRI, provocation tests and patient satisfaction questionnaires were assessed in the study.

Results: At the end of 6 months, there were significant increases in sensory nerve conduction velocity in both intervention and control groups, and the difference between groups were not significant. A higher proportion of subjects using CarpaStretch ${ }^{\circledR}$ showed improvement in severity grade relative to control at 6 months. Small but clinically meaningful increases were seen in carpal tunnel dimensions in the CarpaStretch ${ }^{\circledR}$ group. There was a greater reduction in the incidence of paraesthesia and increase in the time of paraesthesia in the CarpaStretch ${ }^{\circledR}$ group. No adverse effects were reported in either group, but 4 subjects in the control group opted for surgery.

Conclusion: CarpaStretch ${ }^{\circledR}$ can be used for effective non-surgical management of Carpal Tunnel Syndrome.

Keywords: CTS, CarpaStretch ${ }^{\circledR,}$ MRI, NCV

\section{Introduction}

Carpal Tunnel Syndrome (CTS) is a common condition affecting up to $5 \%$ of the population, ${ }^{1}$ and is caused by the compression of the median nerve at the wrist in the carpal tunnel. ${ }^{2}$ The common symptoms are numbness, tingling and pain over the areas supplied by the nerve, which include the thumb, index finger, middle finger and radial part of the ring finger. ${ }^{3,4}$ CTS causes a loss in the working capability and hence can have a significant economic impact on an individual's life. Blue-collar workers and housewives have an increased risk of CTS. ${ }^{5}$

Moreover, manual labor, exposure to vibratory tools and repetitive flexion and extension of the wrist combined with gripping are known risk factors for CTS but the risk from using a computer mouse or keyboard is unclear. ${ }^{6,7,8}$ There are several conservative treatment options such as oral medications, corticosteroid injections and wrist splinting, but their success varies in individual cases.1 Carlson et al., $(2010)^{3}$ have discussed non-surgical management methods for CTS such as bracing, injections, hand/occupational therapy, exercise and other alternative therapies viz., laser, acupuncture, magnetic field therapy and yoga, while Smith et al., (2004) ${ }^{9}$ have reviewed systemic management methods for CTS. CarpaStretch ${ }^{\circledR}$ is a newly developed device for the non-surgical management of CTS using mechanical means. The CarpaStretch ${ }^{\circledR}$ splint stretches the transverse carpal ligament utilizing the proven principles of low-load, prolonged-duration stretch (LLPS), which causes an increase in the lumen of the carpal tunnel. This relieves the pressure on the compressed median nerve and is expected to provide relief to the symptoms of CTS. This was attributed to the prolonged duration of stretching employed by the dynamic splinting system. ${ }^{2,10,11,12,13,14}$ The theory behind the "low-load, prolonged stretching" employed in dynamic splinting originates with the coiled structure of collagen (the primary component in connective tissue). Prolonged stretching at the end-range of motion allows the protein polypeptide binds to realign on the coiled collagen triple helix molecules, thereby elongating the connective tissue. This modality has been shown to be effective in contracture reduction, but analysis in a larger population was recommended. The purpose of this study was to examine the effect of dynamic splinting on 60 patients diagnosed with CTS. 
The present study was conducted with an aim to compare the efficacy and safety of CarpaStretch ${ }^{\circledR}$ relative to wrist splinting in patients with CTS. If CarpaStretch ${ }^{\circledR}$ were to increase the lumen of the carpal tunnel and relieve the pressure onthe median nerve, the changes could be expected are increase in sensory nerve conduction velocity, decrease in paraesthesia by Phalen's and Tinel's tests, increase in time to paraesthesia, increase in dimensions of the carpal tunnel, median nerve by MRI and overall improvement in the quality of life of patients.

\section{Methods}

The trial was a randomized, open label, controlled, parallelgroup, prospective study. Ethical approval was obtained from the Institutional Ethics Committee of Jehangir Clinical Development Centre (Registration No. ECR/352/tnst/MW2013/RR-16) which is accredited by the Association for the Accreditation of Human Research Protection Program (AAHRPP) and National Accreditation Board for Hospitals and Health Care Providers (NABH) (Certificate No. EC-CT-2018-0023). The study subjects were recruited from Jehangir Hospital, Pune, India between March 2015 to July 2016. Patients aged 18-80 years who were diagnosed with CTS by antidromic Nerve Conduction Velocity Test (NCV) were eligible for the study. Patients who had any previous surgery on the affected wrist, trauma to the affected hand that required surgery or immobilization in the previous 12 months, neurological deficit (motor), or any chronic disorder or severe disease were not considered for study participation.

Subjects were randomized in 1:1 allocation ratio using simple randomization to receive the interventional CarpaStretch ${ }^{\circledR}$ or the control treatment. The intervention group was provided with CarpaStretch ${ }^{\circledR}$ to be worn on the affected wrist. The control group received the standard of care which included exercise, a wrist splint and/or NSAIDs as prescribed by the investigator. The treatments were continued for a period of six months with a follow-up of another six months.

\section{CarpaStretch ${ }^{\circledR}$}

The investigational device CarpaStretch $^{\circledR}$ has two components:

Stretching device which is made up of an elastic band (91\% viscose/ 9\% elastodien), Velour Pads (100\% polyamide), elastic foam (100\% silicon), well-loc (polyester/ polypropylene), and a liner (87\% polyamide/ $13 \%$ elastomer).

Two self-adhesive, hypoallergenic pads which have an acrylate based latex free coat on one side (which is in direct contact with the skin). On the upper surface of the adhesive pads, a Velcro pad is provided. The adhesive pads allow a consistent and accurate transmission of the expansion force from a corresponding expansion mechanism. The elastic stretching device allows adjustment of the force applied. The adhesive pads are disposable and can be replaced with new ones when soiled or become loose. The CarpaStretch ${ }^{\circledR}$ device is shown in Figure 1.

\section{Method of Use}

The two adhesive pads are to be removed from the packing and one is to be stuck to thenar eminence and other to hypothenar eminence, distal to flexor wrist crease. The space between the two pads should be equal to the thickness of the little finger. One end of the stretching device should be stuck to the thenar pad by inserting the thumb in the hole and the device wrapped around the palm dorsally and with the other end stuck to the hypothenar pad. A foam pad (100\% silicon) on the stretching device on the dorsal surface of the palm is the main element for applying pressure on the surface of bone. In the study, the device was initially worn daily for one hour. It was increased weekly by one hour up to four weeks and not used at night. After four weeks, it was recommended for use during the night for as long as tolerated, but daytime use for at least four hours was continued till 6 months.

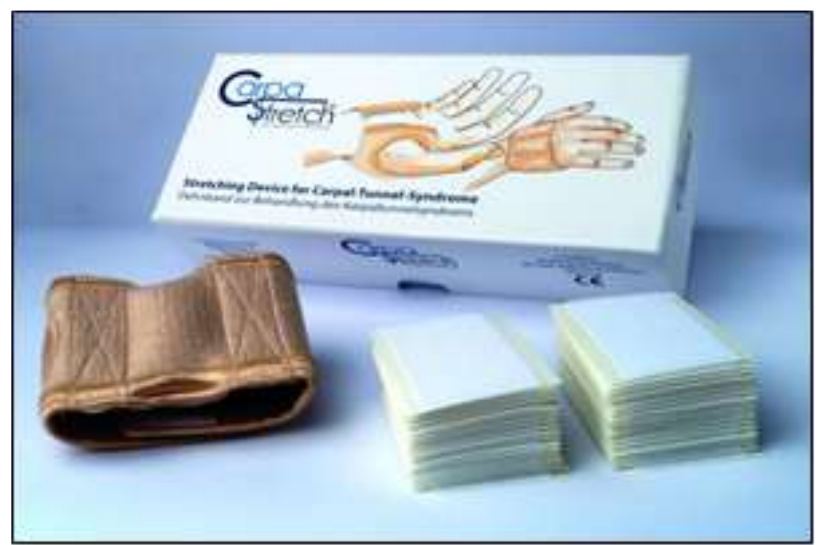

Figure 1. CarpaStretch ${ }^{\circledR}$ Device.

\section{Mechanism of Action}

Low-load, prolonged-duration stretch is the gradual application of tension over time to the connective tissue in a joint, producing a permanent remodelling of the soft tissue. The CarpaStretch ${ }^{\circledR}$ splint stretches the transverse carpal ligament utilizing the proven principles of low-load, prolonged-duration stretch and three point principle used in splint. The detailed mechanism of action is shown in Figure 2.

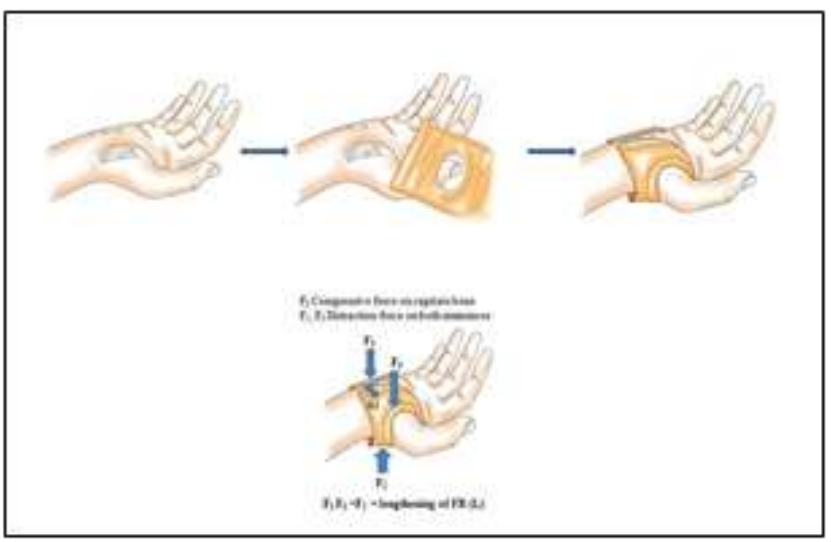

Figure 2. Mechanism of Actions.

\section{Measurements}

\section{Nerve Conduction Test}

The wrist joint of the patients was scanned using RMS EMG EP MK2 System (Model No.F2MG2AB5D116). The surface electrode which is an active electrode was held on abductor pollicis brevis and was stimulated $3 \mathrm{~cm}$ proximal to the wrist crease giving distal motor latency of the median nerve. Sensory nerve conduction study of the median nerve was done by orthodromic stimulation of second digit and recording from median nerve at the wrist. This was done by placing an electrode near the base of the ring finger following which the median nerve was stimulated approximately $13 \mathrm{~cm}$ proximal to the recording electrode. 
The measurements were recorded at baseline, after 6 months of treatment and at the 12 month follow-up.

Data with missing nerve conduction test values at 6 months and 12 months was deleted from the analysis. Nerve conduction test zero values occurring during the study were actually not zero values or missing but rather high severity cases the values were too low to be measured. If basal values were zero but subsequent values non zero, then these basal zero values were replaced by minimum valueof 11.5 $\mathrm{m} / \mathrm{s}$ for statistical analysis. Zero or missing values of nerve conduction test at 6 month or 1 year were replaced by the values obtained by regression method to avoid loss of data.

\section{Wrist MRI}

The wrist joint of the patients was scanned using 3.0 Tesla MRI Super conducting System (Ingenia Release 5, Philips Healthcare, Amsterdam, Netherlands). An axial plane was used and axial T2 and PDF sequences were obtained. The Scan was of $7.5 \mathrm{cms}$ field of view, slice thickness was 3 $\mathrm{mm}$ with $10 \%$ inter slice gap. AP and transverse diameters of the carpal tunnel were measured at the level of pisiform bone. The median nerves measurements were also obtained at the same level in the form of AP and transverse diameters. Additional incidental and clinically relevant findings (ganglion cysts, associated ligament tears, effusions, bony abnormalities) were separately noted. The reporting of all the MRI scans was done by the same radiologist at baseline and after 6 months of treatment.

\section{Provocation Tests}

Phalen's and Tinel's tests ${ }^{15}$ were performed at baseline and at 3, 6, 9 and 12 months. In Phalen's test, patients were asked to flex their wrist 90 degrees and keep it in that position for 60 seconds. A response was considered positive is if it led to paraesthesia along the distribution of the median nerve. Tinel's test was performed by tapping over the volar surface of the wrist distal to proximal of FR. A response was considered positive if it caused paraesthesia in the innervated fingers.

\section{Patients' Satisfaction}

The Boston Carpal Tunnel Syndrome Questionnaire (BCTSQ) is a specific, validated tool used extensively for the assessment of CTS. ${ }^{16}$ This was used in conjunction with the WHO Quality of Life (WHO-QOL) scale to measure the impact of the treatment on the subject. These scales were administered at baseline and at 3, 6, 9 and 12 months. Any subject not satisfied with the treatment was allowed to opt for surgery.

\section{Statistical Methods \\ Sample Size}

The sample size of the study was computed by taking cure rate of $83 \%$ in Intervention group and $40 \%$ in Control group and the end of 12 months. SAS 9.2 computer package was used to calculate sample size. Fisher's exact probability test computed sample size of 30 in each group for $90 \%$ power.

\section{Statistical Analysis}

The primary endpoint of change from baseline in sensory nerve conduction velocity (NCV) was analysed for the treatment groups at 6 and 12 months. The proportion of subjects with change in severity of CTS was computed. The change in carpal tunnel diameters in wrist MRI was assessed at 6 months. From the BCTSQ, the symptom severity and function status scores were computed and the change from baseline was summarized at 3, 6, 9 and 12 months. Change in provocation tests (Phalen's and Tinel's test) and quality of life using WHO-QOL were also analysed at 3, 6, 9 and 12 months. Percentage of subjects referred for surgery was computed. Data analysis was performed using SPSS 15.0 (Statistical Package for Social Sciences Version 15.0).

\section{Results}

Of the 60 subjects randomized in the study, 45 (75\%) completed 6 months and $37(60 \%)$ completed the 12-month follow-up. The mean age of the subjects was $48.3( \pm 12.8)$ years and $82 \%$ were female. Demographic and baseline characteristics of the treatment groups are summarized in Table 1.

Table 1. Demography And Baseline Characteristics.

\begin{tabular}{|c|c|c|c|}
\hline & $\begin{array}{c}\text { Intervention } \\
\qquad(\mathbf{N}=\mathbf{3 0})\end{array}$ & $\begin{array}{l}\text { Control } \\
(\mathrm{N}=30)\end{array}$ & $\begin{array}{l}\text { Comparison } \\
\text { between } \\
\text { Intervention \& } \\
\text { Control } \\
\end{array}$ \\
\hline & $\begin{array}{l}\text { Mean (SD) } \\
\text { or } \mathrm{n} / \mathrm{N}(\%)\end{array}$ & $\begin{array}{c}\text { Mean (SD) } \\
\text { or } \mathrm{n}(\%)\end{array}$ & $\begin{array}{l}\text { Test statistic, } \\
\text { Sign. \& P }\end{array}$ \\
\hline $\begin{array}{l}\text { Age } \\
\text { (years) }\end{array}$ & 47.4 (11.7) & $49.2(14.2)$ & $\mathrm{t}=0.5, \mathrm{NS} . \mathrm{P}=0.6$ \\
\hline $\begin{array}{l}\text { Gender } \\
(\% \\
\text { female })\end{array}$ & $\begin{array}{c}25 / 30 \\
(83.3 \%)\end{array}$ & $\begin{array}{l}24 / 30 \\
(80 \%)\end{array}$ & $\mathrm{F}=1.0, \mathrm{NS}, \mathrm{P}=1.0$ \\
\hline $\begin{array}{l}\text { Bilateral } \\
\text { CTS } \\
\text { Severity } \\
\text { of CTS }\end{array}$ & $\begin{array}{c}23 / 30 \\
(76.7 \%)\end{array}$ & $\begin{array}{c}19 / 30 \\
(63.3 \%)\end{array}$ & $\mathrm{F}=0.4, \mathrm{NS}, \mathrm{P}=0.4$ \\
\hline Mild & $6 / 30(20 \%)$ & $\begin{array}{c}7 / 30 \\
(23.3 \%)\end{array}$ & $\begin{array}{l}\text { Chi.sq. }=0.9, \mathrm{DF}= \\
2, \mathrm{P}=0.6\end{array}$ \\
\hline Moderate & $9 / 30(30 \%)$ & $\begin{array}{l}12 / 30 \\
(40 \%)\end{array}$ & \\
\hline Severe & $15 / 30(50 \%)$ & $\begin{array}{c}11 / 30 \\
(36.7 \%)\end{array}$ & \\
\hline $\begin{array}{l}\text { Sensory } \\
\text { NCV } \\
(\mathrm{mS})\end{array}$ & $24.55(19.80)$ & $\begin{array}{c}30.18 \\
(21.92)\end{array}$ & \\
\hline
\end{tabular}

Sign.=Significance, $\mathrm{P}=$ Probability value, $\mathrm{S}=$ Significant, NS=Not Significant,Chi.sq.=Chi square value, $\mathrm{t}=$ Student's $\mathrm{t}$ test value, $\mathrm{F}=$ Fisher's Exact Probability test, $\mathrm{DF}=$ Degrees of Freedom.

Statistical tests applied: Student's unpaired t test, Fisher Exact Probability test and Chi sq.test.

Conclusion: No significant difference between 2 groups implying both groups were similar at baseline.

Results of the nerve conduction tests (Table 2a) showed significant increases in sensory NCV at 6 months and at 1 year for intervention group as well as for control group. Increase in sensory NCV in Intervention group was 8.43 $\mathrm{m} / \mathrm{s}$ which was highly significant $(\mathrm{P}<0.01)$ as compared to Basal value. There was increase of $7.30 \mathrm{~m} / \mathrm{s}$ in Control group which was also significant $(\mathrm{P}<0.05)$. There was no significant difference between increase in Intervention Group and Control at 6 months.

Similarly increase in sensory NCV in Intervention group at 1 year was $10.13 \mathrm{~m} / \mathrm{s}$ which was statistically significant $(\mathrm{P}<0.01)$ as compared to Basal value. There was significant increase of $8.66 \mathrm{~m} / \mathrm{s}$ in Control group as compared to Basal at 1 year which was significant $(\mathrm{P}<0.05)$. Comparison of increase in NCV between Intervention and Control group (Table 2b) indicated that the increase at 6 months and at 1 
year was similar (no significant difference) between Intervention Group and Control group.

Table 2a. Nerve Conduction Velocity Test (Sensory Ncv (Ms)).

\begin{tabular}{lccc}
\hline & \multicolumn{3}{c}{ Intervention } \\
\hline & $\mathrm{N}$ & \multicolumn{1}{c}{ Mean (SD) } & $\begin{array}{c}\text { Change from Baseline } \\
(95 \% \mathrm{CI})\end{array}$ \\
Baseline & 17 & $35.51(11.05)$ & \\
Month 6 & 17 & $43.94(8.41)$ & $8.43^{* *}(3.40,13.46)$ \\
Month 12 & 17 & $45.64(9.51)$ & $10.13^{* *}(3.61,16.65)$ \\
\hline & \multicolumn{3}{c}{ Control Group } \\
\hline & $\mathrm{N}$ & Mean (SD) & Change from Baseline \\
Baseline & 16 & $37.78(6.66)$ & $(95 \%$ CI $)$ \\
Month 6 & 16 & $45.08(8.48)$ & $7.30 *(0.04,14.56)$ \\
Month 12 & 16 & $46.45(8.18)$ & $8.67 *(1.12,16.21)$ \\
\hline
\end{tabular}

Statistical tests applied: Student's paired t test.

*: Significant at the 5\% level, ${ }^{* *}$ : Significant at the $1 \%$ level.

Conclusions: Significant increase in NCV as compared to basal for Intervention \& Control at 6 months \& 12 months.

Table 2b: Nerve Conduction Velocity Test (Sensory Ncv (Ms)).

Comparison of Increase in Sensory NCV at the end of 6 months and 1 year

\begin{tabular}{|c|c|c|c|}
\hline & Intervention & Control & $\begin{array}{l}\text { t value, Significance } \\
\& \text { P value }\end{array}$ \\
\hline $\begin{array}{l}\text { End of } 6 \\
\text { months } \\
\text { (6 } \\
\text { months- }\end{array}$ & $8.43 \pm 9.78$ & $\begin{array}{l}7.30 \pm \\
13.62\end{array}$ & $\mathrm{t}=0.3, \mathrm{NS}, \mathrm{P}=0.8$ \\
\hline $\begin{array}{l}\text { Basal) } \\
\text { End of } 12 \\
\text { months } \\
\text { (12 months- } \\
\text { Basal) }\end{array}$ & $10.13 \pm 12.69$ & $\begin{array}{l}8.56 \pm \\
14.17\end{array}$ & $\mathrm{t}=0.3, \mathrm{NS}, \mathrm{P}=0.8$ \\
\hline
\end{tabular}

Conclusions: No significant difference in increase in NCV between Intervention \& Control at 6 months \& 12 months.

Table 3. Change In Severity Of Cts.

\begin{tabular}{llll}
\hline & Intervention & Control & $\begin{array}{l}\text { Comparison } \\
\text { between } \\
\text { Intervention } \\
\text { \& Control }\end{array}$ \\
\hline n/N (\%) & $\mathbf{n} / \mathbf{N}(\%)$ & \\
\hline \multicolumn{5}{c}{ Baseline to Month $\mathbf{6}$} \\
Improved & $11 / 17(66.7 \%)$ & $8 / 16$ \\
& & $(50.0 \%)$ & \\
Unchanged & $6 / 17(35.3 \%)$ & $2 / 16$ & \\
& & $(12.5 \%)$ & Chi.sq. $=8.5, \mathrm{D}$ \\
Worsened & $0 / 17(0.0 \%)$ & $6 / 16$ & $\mathrm{~F}=2, \mathrm{~S}, \mathrm{P}=0.01$ \\
& & $(37.5 \%)$ & 5 \\
\hline
\end{tabular}

\section{Baseline to Month 12}

\begin{tabular}{|c|c|c|c|}
\hline Improved & $12 / 17(70.0 \%)$ & $\begin{array}{l}4 / 16 \\
(25.0 \%)\end{array}$ & \\
\hline Unchanged & $4 / 17(23.5 \%)$ & $\begin{array}{l}7 / 16 \\
(43.8 \%)\end{array}$ & \\
\hline Worsened & $1 / 17(5.9 \%)$ & $\begin{array}{l}5 / 16 \\
(31.3 \%)\end{array}$ & $\begin{array}{l}\text { Chi.sq. }=7.5, \mathrm{D} \\
\mathrm{F}=2, \mathrm{~S}, \mathrm{P}=0.02 \\
4\end{array}$ \\
\hline
\end{tabular}

Statistical test applied: Chi square test

Conclusion: Significant difference between Intervention and Control at 6 months and at 12 months.

Improvement in severity of CTS is denoted as a reduction of at least one point in severity grading. The proportion of subjects who had an improvement in CTS severity (Table
3) after 6 months of treatment was higher in the intervention group relative to control at 6 months and at one year. This difference was statistically significant by Chi square test at 6 months and 1 year concluding that Intervention had cured significantly more number of subjects than Control group.

From the wrist MRI (Table 4), small but clinically meaningful improvements in carpal tunnel transverse diameters (median nerve, bony and soft tissue) were observed at 6 months in the intervention group. Such improvements were not seen consistently in the control group.

Table 4. Carpal Tunnel Diameters by Wrist MRI.

\begin{tabular}{|c|c|c|c|}
\hline \multirow{2}{*}{$\begin{array}{c}\text { Carpal tunnel } \\
\text { diameters } \\
\text { (transverse) }(\mathbf{m m})\end{array}$} & \multicolumn{3}{|c|}{ Intervention } \\
\hline & Baseline & 6 month & $\begin{array}{c}\text { Change } \\
\text { from } \\
\text { baseline }\end{array}$ \\
\hline & $\mathrm{N}=30$ & $\mathrm{~N}=25$ & $(95 \% \mathrm{CI})$ \\
\hline Bony proximal & $\begin{array}{l}22.0 \\
(2.97)\end{array}$ & $\begin{array}{l}22.53 \\
(2.36)\end{array}$ & $\begin{array}{c}0.52(-0.81 \\
1.85)\end{array}$ \\
\hline Bony distal & $\begin{array}{l}19.98 \\
(3.89)\end{array}$ & $\begin{array}{l}20.19 \\
(2.06)\end{array}$ & $\begin{array}{c}0.47(-1.14, \\
2.07)\end{array}$ \\
\hline $\begin{array}{r}\text { Soft tissue } \\
\text { proximal }\end{array}$ & $\begin{array}{l}19.52 \\
(3.31)\end{array}$ & $\begin{array}{l}20.68 \\
(2.20)\end{array}$ & $\begin{array}{c}1.30(-0.24, \\
2.85)\end{array}$ \\
\hline Soft tissue distal & $\begin{array}{l}18.35 \\
(3.51)\end{array}$ & $\begin{array}{l}18.74 \\
(2.52)\end{array}$ & $\begin{array}{c}0.61(-1.02, \\
2.25)\end{array}$ \\
\hline $\begin{array}{r}\text { Median nerve } \\
\text { proximal }\end{array}$ & $\begin{array}{l}6.29 \\
(1.36)\end{array}$ & $6.44(1.05)$ & $\begin{array}{c}0.08(-0.51, \\
0.68)\end{array}$ \\
\hline $\begin{array}{r}\text { Median nerve } \\
\text { distal } \\
\end{array}$ & $\begin{array}{l}5.73 \\
(1.03) \\
\end{array}$ & $6.04(1.06)$ & $\begin{array}{c}0.29(-0.27, \\
0.86)\end{array}$ \\
\hline \multirow{2}{*}{$\begin{array}{c}\text { Carpal tunnel } \\
\text { diameters } \\
\text { (transverse) }(\mathbf{m m})\end{array}$} & \multicolumn{3}{|c|}{ Control } \\
\hline & Baseline & 6 month & $\begin{array}{c}\text { Change } \\
\text { from } \\
\text { baseline }\end{array}$ \\
\hline & $\mathrm{N}=30$ & $\mathrm{~N}=20$ & $(95 \% \mathrm{CI})$ \\
\hline Bony proximal & $\begin{array}{l}22.14 \\
(3.81)\end{array}$ & $\begin{array}{l}22.57 \\
(3.31)\end{array}$ & $\begin{array}{c}0.80(-1.62, \\
3.22)\end{array}$ \\
\hline Bony distal & $\begin{array}{l}19.82 \\
(4.17)\end{array}$ & $\begin{array}{l}19.33 \\
(3.57)\end{array}$ & $\begin{array}{c}-0.11(-2.89, \\
2.67)\end{array}$ \\
\hline $\begin{array}{r}\text { Soft tissue } \\
\text { proximal }\end{array}$ & $\begin{array}{l}19.75 \\
(3.85)\end{array}$ & $\begin{array}{l}20.33 \\
(3.06)\end{array}$ & $\begin{array}{c}1.05(-1.38, \\
3.48)\end{array}$ \\
\hline Soft tissue distal & $\begin{array}{l}18.52 \\
(3.93)\end{array}$ & $\begin{array}{l}18.19 \\
(3.06)\end{array}$ & $\begin{array}{c}-0.24(-2.69, \\
2.22)\end{array}$ \\
\hline $\begin{array}{r}\text { Median nerve } \\
\text { proximal }\end{array}$ & $\begin{array}{l}6.32 \\
(1.82)\end{array}$ & $6.17(1.16)$ & $\begin{array}{c}-0.20(-1.34, \\
0.94)\end{array}$ \\
\hline $\begin{array}{r}\text { Median nerve } \\
\text { distal }\end{array}$ & $\begin{array}{l}5.35 \\
(1.37)\end{array}$ & $5.82(1.54)$ & $\begin{array}{c}0.54(-0.40, \\
1.48)\end{array}$ \\
\hline
\end{tabular}

Conclusion: Overall change in above parameters.

Table 5. Provocation Tests (Phalen's and Tinel's) for Paraesthesia.

\section{Phalen's Test}

\section{P-value}

\begin{tabular}{|c|c|c|c|c|c|}
\hline & \multicolumn{2}{|c|}{ Intervention } & \multicolumn{2}{|c|}{ Control } & \\
\hline & $\mathrm{N}$ & $\mathrm{n}(\%)$ & $\mathrm{N}$ & $\mathrm{n}(\%)$ & \\
\hline Baseline & 30 & $29(96.7 \%)$ & 30 & $\begin{array}{l}29 \\
(96.7 \%)\end{array}$ & 1.00 \\
\hline Month 3 & 24 & $20(83.3 \%)$ & 25 & $20(80 \%)$ & 1.00 \\
\hline Month 6 & 25 & $16(64 \%)$ & 20 & $14(70 \%)$ & 0.916 \\
\hline Month 9 & 22 & $9(40.9 \%)$ & 15 & $\begin{array}{l}11 \\
(73.3 \%)\end{array}$ & 0.108 \\
\hline $\begin{array}{l}\text { Month } \\
12\end{array}$ & 21 & $6(28.6 \%)$ & 17 & $\begin{array}{l}12 \\
(70.6 \%)\end{array}$ & 0.024 \\
\hline
\end{tabular}

Conclusion: Phalen test detected Significant difference at 12 months. 


\begin{tabular}{|c|c|c|c|c|}
\hline \multicolumn{5}{|c|}{ Tinel's Test } \\
\hline \multicolumn{2}{|c|}{ Intervention } & \multicolumn{2}{|c|}{ Control } & P. \\
\hline $\mathrm{N}$ & $\mathrm{n}(\%)$ & $\mathrm{N}$ & $\mathrm{n}(\%)$ & value§ \\
\hline 30 & $27(90 \%)$ & 30 & $22(73.33 \%)$ & 1.00 \\
\hline 24 & $11(45.8 \%)$ & 25 & $11(44 \%)$ & 1.00 \\
\hline 25 & $2(8 \%)$ & 20 & $6(30 \%)$ & 0.127 \\
\hline 22 & $2(9.1 \%)$ & 15 & $4(26.67 \%)$ & 0.332 \\
\hline 21 & $1(4.8 \%)$ & 17 & $5(29.41 \%)$ & 0.104 \\
\hline
\end{tabular}

\begin{tabular}{llrlrr}
\hline & \multicolumn{5}{c}{ Time of Paraesthesia (sec) } \\
\hline & N & Median & N & Median & P-value $\uparrow$ \\
Baseline & 30 & 15 & 30 & 20 & 0.167 \\
Month 3 & 24 & 25 & 25 & 20 & 0.254 \\
Month 6 & 25 & 32.5 & 20 & 20 & 0.054 \\
Month 9 & 22 & 30 & 15 & 30 & 0.644 \\
Month 12 & 21 & 42.5 & 17 & 32.5 & 0.120 \\
\hline
\end{tabular}

$\S$ from Chi-square test, $\uparrow$ from Wilcoxon test.

Statistical tests applied: Chi square test and Wilcoxon Signed Rank test.

The Phalen's test (Table 5) showed a significant reduction in both treatment groups in the proportion of subjects who experienced paraesthesia. The reductions were significantly larger $(\mathrm{P}=0.024)$ in the intervention group than in the control group at Month 12. In both groups, there was a significant increase in the time to paraesthesia, but the between-group differences were not significant. Results from Tinel's test (Table 5) are similar to that of Phalen's test, with significant reductions in both treatment groups in the incidence of paraesthesia.

Table 6. Boston Carpal Tunnel Syndrome Questionnaire (BCTSQ).

\begin{tabular}{|c|c|c|c|c|}
\hline & \multicolumn{4}{|c|}{ Symptom Severity Scale Score } \\
\hline & \multicolumn{2}{|c|}{ Intervention } & \multicolumn{2}{|c|}{ Control } \\
\hline & $\begin{array}{l}\text { Mean } \\
\text { (SD) }\end{array}$ & $\begin{array}{c}\text { Change from } \\
\text { Baseline* } \\
(95 \% \mathrm{CI})\end{array}$ & $\begin{array}{l}\text { Mean } \\
\text { (SD) }\end{array}$ & $\begin{array}{c}\text { Change from } \\
\text { Baseline* } \\
(95 \% \text { CI })\end{array}$ \\
\hline Baseline & $\begin{array}{l}1.91 \\
(0.81)\end{array}$ & & $\begin{array}{l}1.85 \\
(0.97)\end{array}$ & \\
\hline Month 3 & $\begin{array}{l}1.23 \\
(0.86)\end{array}$ & $\begin{array}{l}-0.72(-1.00,- \\
0.44)\end{array}$ & $\begin{array}{l}1.36 \\
(0.81)\end{array}$ & $\begin{array}{l}-0.55(-0.88,- \\
0.22)\end{array}$ \\
\hline Month 6 & $\begin{array}{l}1.05 \\
(0.64)\end{array}$ & $\begin{array}{l}-0.89(-1.21,- \\
0.58)\end{array}$ & $\begin{array}{l}0.97 \\
(0.83)\end{array}$ & $\begin{array}{l}-0.93(-1.41,- \\
0.45)\end{array}$ \\
\hline Month 9 & $\begin{array}{l}0.83 \\
(0.75)\end{array}$ & $\begin{array}{l}-1.10(-1.46,- \\
0.74)\end{array}$ & $\begin{array}{l}0.95 \\
(0.89)\end{array}$ & $\begin{array}{l}-0.81(-1.39,- \\
0.23)\end{array}$ \\
\hline \multirow[t]{4}{*}{$\begin{array}{l}\text { Month } \\
12\end{array}$} & $\begin{array}{l}0.72 \\
(0.68)\end{array}$ & $\begin{array}{l}-1.16(-1.56,- \\
0.75)\end{array}$ & $\begin{array}{l}0.83 \\
(0.87)\end{array}$ & $\begin{array}{l}-0.83(-1.45,- \\
0.21)\end{array}$ \\
\hline & \multicolumn{4}{|c|}{ Functional Status Scale Score } \\
\hline & \multicolumn{2}{|c|}{ Intervention } & \multicolumn{2}{|c|}{ Control } \\
\hline & $\begin{array}{l}\text { Mean } \\
(\mathrm{SD})\end{array}$ & $\begin{array}{c}\text { Change from } \\
\text { Baseline* } \\
\text { (95\% CI) }\end{array}$ & $\begin{array}{l}\text { Mean } \\
\text { (SD) }\end{array}$ & $\begin{array}{l}\text { Change from } \\
\text { Baseline* } \\
(95 \% \mathrm{CI})\end{array}$ \\
\hline Baseline & $\begin{array}{l}1.45 \\
(1.07)\end{array}$ & & $\begin{array}{l}1.46 \\
(1.20)\end{array}$ & \\
\hline Month 3 & $\begin{array}{l}1.08 \\
(0.84)\end{array}$ & $\begin{array}{l}-0.40(-0.69,- \\
0.11)\end{array}$ & $\begin{array}{l}1.08 \\
(1.04)\end{array}$ & $\begin{array}{l}-0.46(-0.83,- \\
0.08)\end{array}$ \\
\hline Month 6 & $\begin{array}{l}0.70 \\
(0.63)\end{array}$ & $\begin{array}{l}-0.84(-1.23,- \\
0.44)\end{array}$ & $\begin{array}{l}0.72 \\
(1.07)\end{array}$ & $\begin{array}{l}-0.85(-1.43,- \\
0.27)\end{array}$ \\
\hline Month 9 & $\begin{array}{l}0.58 \\
(0.69)\end{array}$ & $\begin{array}{l}-0.85(-1.33,- \\
0.38)\end{array}$ & $\begin{array}{l}0.54 \\
(0.97)\end{array}$ & $\begin{array}{l}-0.93(-1.58,- \\
0.28)\end{array}$ \\
\hline $\begin{array}{l}\text { Month } \\
12\end{array}$ & $\begin{array}{l}0.60 \\
(0.75)\end{array}$ & $\begin{array}{l}-0.71(-1.30,- \\
0.11)\end{array}$ & $\begin{array}{l}0.63 \\
(0.97)\end{array}$ & $\begin{array}{l}-0.79(-1.52,- \\
0.06)\end{array}$ \\
\hline
\end{tabular}

*Changes from baseline were significant at all time points at the $5 \%$ level.
Both treatment groups had significant improvements in symptom severity and functional status of the BCTSQ (Table 6) at all-time points in the study. The between-group differences in BCTSQ were not statistically significant. Analysis of the WHO-QOL scores (Table 7) showed a significant improvement in physical domain at 6 months in the intervention group. The control group had no statistically significant improvement at any time point in the study.

No adverse effects were observed in either group, but 4 subjects from the control group and none from the intervention group opted for surgery.

Table 7. WHO-QOL Scores.

\begin{tabular}{|c|c|c|c|c|}
\hline & \multicolumn{4}{|c|}{ Symptom Severity Scale Score } \\
\hline & \multicolumn{2}{|c|}{ Intervention } & \multicolumn{2}{|c|}{ Control } \\
\hline & $\begin{array}{l}\text { Mean } \\
(\mathrm{SD})\end{array}$ & $\begin{array}{c}\text { Change } \\
\text { from } \\
\text { Baseline } \\
(95 \% \mathrm{CI})\end{array}$ & $\begin{array}{l}\text { Mean } \\
(\mathrm{SD})\end{array}$ & $\begin{array}{c}\text { Change from } \\
\text { Baseline* }(95 \% \\
\text { CI) }\end{array}$ \\
\hline Baseline & $\begin{array}{l}1.91 \\
(0.81)\end{array}$ & & $\begin{array}{l}1.85 \\
(0.97)\end{array}$ & \\
\hline Month 3 & $\begin{array}{l}1.23 \\
(0.86)\end{array}$ & $\begin{array}{l}-0.72(- \\
1.00,- \\
0.44)\end{array}$ & $\begin{array}{l}1.36 \\
(0.81)\end{array}$ & $\begin{array}{l}-0.55(-0.88,- \\
0.22)\end{array}$ \\
\hline Month 6 & $\begin{array}{l}1.05 \\
(0.64)\end{array}$ & $\begin{array}{l}-0.89(- \\
1.21,- \\
0.58)\end{array}$ & $\begin{array}{l}0.97 \\
(0.83)\end{array}$ & $\begin{array}{l}-0.93(-1.41,- \\
0.45)\end{array}$ \\
\hline Month 9 & $\begin{array}{l}0.83 \\
(0.75)\end{array}$ & $\begin{array}{l}-1.10(- \\
1.46,- \\
0.74)\end{array}$ & $\begin{array}{l}0.95 \\
(0.89)\end{array}$ & $\begin{array}{l}-0.81(-1.39,- \\
0.23)\end{array}$ \\
\hline $\begin{array}{l}\text { Month } \\
12\end{array}$ & $\begin{array}{l}0.72 \\
(0.68)\end{array}$ & $\begin{array}{l}-1.16(- \\
1.56,- \\
0.75)\end{array}$ & $\begin{array}{l}0.83 \\
(0.87)\end{array}$ & $\begin{array}{l}-0.83(-1.45,- \\
0.21)\end{array}$ \\
\hline \multicolumn{5}{|c|}{ Functional Status Scale Score } \\
\hline \multicolumn{3}{|c|}{ Intervention } & \multicolumn{2}{|c|}{ Control } \\
\hline $\begin{array}{l}\text { Mean } \\
\text { (SD) }\end{array}$ & \multicolumn{2}{|c|}{$\begin{array}{c}\text { Change from } \\
\text { Baseline* }(95 \% \\
\text { CI) }\end{array}$} & $\begin{array}{l}\text { Mean } \\
(\mathrm{SD})\end{array}$ & $\begin{array}{c}\text { Change from } \\
\text { Baseline* }(95 \% \\
\text { CI })\end{array}$ \\
\hline $\begin{array}{l}1.45 \\
(1.07)\end{array}$ & & & $\begin{array}{l}1.46 \\
(1.20)\end{array}$ & \\
\hline $\begin{array}{l}1.08 \\
(0.84)\end{array}$ & \multicolumn{2}{|c|}{$-0.40(-0.69,-0.11)$} & $\begin{array}{l}1.08 \\
(1.04)\end{array}$ & $-0.46(-0.83,-0.08)$ \\
\hline $\begin{array}{l}0.70 \\
(0.63)\end{array}$ & \multicolumn{2}{|c|}{$-0.84(-1.23,-0.44)$} & $\begin{array}{l}0.72 \\
(1.07)\end{array}$ & $-0.85(-1.43,-0.27)$ \\
\hline $\begin{array}{l}0.58 \\
(0.69)\end{array}$ & \multicolumn{2}{|c|}{$-0.85(-1.33,-0.38)$} & $\begin{array}{l}0.54 \\
(0.97)\end{array}$ & $-0.93(-1.58,-0.28)$ \\
\hline $\begin{array}{l}0.60 \\
(0.75)\end{array}$ & \multicolumn{2}{|c|}{$-0.71(-1.30,-0.11)$} & $\begin{array}{l}0.63 \\
(0.97)\end{array}$ & $-0.79(-1.52,-0.06)$ \\
\hline
\end{tabular}

*: Significant at the $5 \%$ level

\section{Discussion}

The purpose of this prospective study was to examine the effect of CarpaStretch ${ }^{\circledR}$ on 60 patients diagnosed with CTS. The success of this treatment modality is hypothesized to be derived from prolonged, end-range stretching of the transverse palmar carpal ligament and the flexor retinaculum, because contracture of these structures contributes to compression in CTS. Dynamic tension and prolonged stretching have been successful in contracture reduction from head to toe, trismus 14 to hallux rigidus. ${ }^{12}$ The low-load, prolonged duration of end-range stretching is hypothesized to be responsible for elongation of the connective tissue. Unlike traditional "positioning splints" which are simply designed to prevent the patient from aggravating their CTS condition, the patients treated with 
the dynamic splint are instructed to simply rest the device on their lap during the treatment periods for a cumulative time of 60 minutes per day.

This paper showed that the new modality was effective in reducing symptoms and improving function in patients diagnosed with CTS. This study is also an answer to recommendations for further investigation of non-surgical treatments for CTS. ${ }^{2,17-23}$

This was the first hospital based randomized trial of CarpaStretch $^{\circledR}$ device compared with the conventional wrist splint for patients with CTS. During the 6 months of the study, and the 12-month follow-up, the anatomical and functional changes noted may be increase in sensory NCV and improvement in CTS severity at 6 months, small but clinically meaningful improvements in carpal tunnel transverse diameters (median nerve, bony proximal and soft tissue) at 6 months, reduced incidence and increased time to paraesthesia over 12 months, improved Boston Carpal Tunnel Syndrome Questionnaire and WHO-QOL (physical domain) scores over 12 months.

These changes were seen consistently in the intervention group and less frequently in the control group. There were no adverse events associated with its use. This suggests that CarpaStretch ${ }^{\circledR}$ is safe for use. In addition, CarpaStretch ${ }^{\circledR}$ is simpler to use, and so is expected to be of greater benefit to patients over methods like splinting.

Many interventional studies have reported the comparison of the effects of different therapies for the treatment of CTS (YOGA therapy vs splint, splint vs surgery, surgery vs steroid. Yoga and surgical interventions were found to be effective.

Uchiyama et al., $(2005)^{24}$ who studied quantitative MRI of the wrist and nerve conduction found that severity of the disease could be judged by evaluating not only longitudinal changes of signal intensity, and configuration of the median nerve, but also palmar bowing of the Transverse Carpal Ligament (TCL) and this was found to be associated with an increase in the area of the carpal tunnel. International Guidelines for CTS $(2017)^{1}$ presently recommend only splint and surgery as methods of treatment (Lim et al., 2017), due to which the present results become clinically important. Berner (2008) et al, ${ }^{18}$ reported that CTS is treated with dynasplint and C-TRAC but results were assessed on the basis of symptom relief. This is first study to explore an effect of this device on carpal tunnel. Sucher et al, $2005^{26}$ observed increase in the length of the transverse carpal ligament after doing manipulative treatment and along with dynamic orthosis should be more effective.

This study is the first to explore the effect of this nonsurgical intervention in Indians. Most intervention studies on CTS have used NCV and provocation tests. But our study also includes MRI of the wrist and subjective improvement, as well as quality of life of the patient. Being an interventional study, the authors were able to compare the change in MRI measurements over a period of six months. However, the MRI was not done at the 12 month follow-up, so the authors could not observe if the improvements attained with CarpaStretch ${ }^{\circledR}$ at 6 months would have continued up to 12 months. There has been only one study in the past which measured multiple parameters to assess prognosis in CTS. ${ }^{27,28}$ There are many parameters to assess the efficacy of CTS treatments. The present study demonstrates that CarpaStretch ${ }^{\circledR}$ affects some of these parameters, while establishing statistical superiority of the device over conventional wrist splint treatment in a few of these parameters.

It is worth mentioning that 4 subjects in the control group, but none in the intervention group were referred for surgery, although the intervention group had more severe subjects at baseline. Further studies would establish the advantages of the device more conclusively and provide evidence for the mechanism of action that has been proposed. Though the intervention group showed significant improvement in some WHO-QOL parameters, it should be noted that $77 \%$ of the subjects in this group had bilateral CTS and only one arm was selected for treatment with CarpaStretch ${ }^{\circledR}$. Hence the results of the WHO-QOL tests should be interpreted with some caution. Still, the improvement in these scores in the intervention group may be attributed to the user-friendliness of the device. It can be used through the day and is easy to apply and remove. It also eliminates the need for corticosteroid injections which are known to cause pain and other adverse reactions. Overall, CarpaStretch ${ }^{\circledR}$ proves to be a better treatment option, though the authors cannot deny that conventional therapy is also effective.

\section{Conclusion}

The authors conclude that CarpaStretch ${ }^{\circledR}$ is a novel, effective and safe device for the treatment of CTS. It is also user-friendly and does not hamper daily living.

\section{Acknowledgement}

This work was supported by Sponsor ConInvent from Germany. The authors would to express their sincere thanks to Dr. Ravindra Ghooi and Dr. Mukund Thatte for critically reviewing this work and biostatistics, Mrs. Jayanti Gupta for analyzing the statistics.

\section{References}

1. Carpal tunnel syndrome fact sheet. National Institute of Neurological Disorders and Stroke. 2016;28

2. Mishra S, Prabhakar S, Lal V, Modi M, Das CP, Khurana D. Efficacy of splinting and oral steroids in the treatment of carpal tunnel syndrome: a prospective randomized clinical and electrophysiological study. Neurol India; 2006.54(3);286-290. PubMed: https://www.ncbi.nlm.nih.gov/pubmed/16936391

3. Carlson H, Colbert A, Frydl J, Arnall E, Eliot M, Carlson N. Current options for nonsurgical management of carpal tunnel syndrome. Int $\mathrm{J}$ Clin. Rheumtol; 2010.5:129-142. PubMed: https://www.ncbi.nlm.nih.gov/pubmed/20490348\#

4. Ibrahim I, Khan W, Goddard N, Smitham P. Carpal tunnel syndrome: a review of the recent literature. The Open Orthopaedics Journal; 2012. 6 (Suppl 1: M8) 69-79. DOI: 10.2174/1874325001206010069

5. Mattioli S, Baldasseroni A, Curti S, et al. Incidence rates of surgically treated idiopathic carpal tunnel syndrome in blue- and white-collar workers and housewives in tuscany italy. Occupational and 
Environmental Medicine; 2009.66:299-304. DOI: [10.1136/oem.2008.040212]

6. Armstrong T, Dale AM, Franzblau A, Evanoff BA. Risk factors for carpal tunnel syndrome and median neuropathy in a working population. Occupational and Environmental Medicine; 2008.(50)1355-1364. DOI: 10.1097/JOM.0b013e3181845fb1

7. Thomsen JF, Gerr F, Atroshi I. Carpal tunnel syndrome and the use of computer mouse and keyboard: a systematic review. BMC Musculoskelet. Disord; 2008.9-134. DOI: [10.1186/1471-2474-9134]

8. Somaiah A, Spence R. Carpal tunnel syndrome: review. Ulster Med J; 2008.77 (1) 6-17

9. Smith F, Arroll B. What can family physicians offer patients with carpal tunnel syndrome other than surgery? a systematic review of nonsurgical management. Ann Fam Med; 2004.2(3):267-73. PubMed:

https://www.ncbi.nlm.nih.gov/pubmed/15209206

10. Craft RO, Duncan SF, Smith AA. Management of recurrent carpal tunnel syndrome with microneurolysis and the hypothenar fat pad flap. HAND; 2007.(2)2:85-89. DOI: [10.1007/s11552-0079025-7]

11. John MM, Willis FB, Protillo A. Runner's hallux rigidus reduction and gait analysis. J. Am. Podiatric Med. Assoc.; 2009.99(4):367-370

12. Willis B. Dynamic splinting increases flexion for hallux rigidus (pilot study). BioMech; 2007.14(9):4953

13. Gaspar PD, Willis FB. Adhesive capsulitis and dynamic splinting: a controlled, cohort study. BMC Musculoskeletal Disorders; 2009.10: 111-115. DOI: 10.1186/1471-2474-10-111

14. Shulman DH, Shipman B, Willis FB. Treating trismus with dynamic splinting: a cohort, case series. Adv. Ther; 2008.25(1):9-15. DOI: 10.1007/s12325-0080007-0

15. Brüske J, Bednarski M, Grzelec H, Zyluk A. The usefulness of the phalen test and the hoffmann-tinel sign in the diagnosis of carpal tunnel syndrome. Acta Orthop Belg; 2002.68:141-5

16. Greenslade JR, Mehta RL, Belward P, Warwick DJ. Dash and boston questionnaire assessment of carpal tunnel syndrome outcome: what is the responsiveness of an outcome questionnaire? $\mathrm{j}$ hand surg br; 2004.29:159-64. DOI: 10.1016/j.jhsb.2003.10.010

17. Atroshi I, Gummesson C, Johnsson R, Ornstein E, Ranstam J, Rosén I. Prevalence of carpal tunnel syndrome in a general population. JAMA; 1999.282(2): 153-8
18. Berner SH, Willis FB, Martinez J. Treatment of carpal tunnel syndrome with dynasplint: a randomized, controlled trial. J. Med.; 1999.(1):90-94

19. Burke FD, Wilgis EF, Dubin NH, Bradley MJ, Sinha S. Relationship between the duration and severity of symptoms and the outcome of carpal tunnel surgery. J. Hand Surg. [Am.]; 2006.31(9): 1478-82

20. De Stefano F, Nordstrom DL, Vierkant RA. Longterm symptom outcomes of carpal tunnel syndrome and its treatment. J. Hand Surg.; 1997.22(2): 200-10. DOI: 10.1016/S0363-5023(97)80152-9

21. Palmer KT, Harris EC, Coggon D. Carpal tunnel syndrome and its relation to occupation: a systematic literature review. Occup Med.; 2007.57(1):57-66. DOI: $10.1093 /$ occmed/kql125

22. Gerritsen AA, de Vet HC, Scholten RJ, Bertelsmann FW, de Krom MC, Bouter LM. Splinting vs surgery in the treatment of carpal tunnel syndrome: a randomized controlled trial. JAMA; 2002.288:1245-1251. PubMed:

https://www.ncbi.nlm.nih.gov/pubmed/12215131

23. Ramos-Zúñiga R, García-Mercado C, Segura-Durán I, Zepeda-Gutiérrez L. Efficacy of keyhole approach to carpal tunnel syndrome under ambulatory strategy. Neurology Res. Int.; 2017.1-6

24. Uchiyama S, Itsubo $\mathrm{T}$, Yasutomi $\mathrm{T}$, Nakagawa $\mathrm{H}$, Kamimura M, Kato H. Quantitative mri of the wrist and nerve conduction studies in patients with idiopathic carpal tunnel syndrome. J Neurol Neurosurg Psychiatry; 2005.76:1103-1108. DOI: [10.1136/jnnp.2004.051060]

25. Lim YH, Chee DY, Girdler S, Lee HC. Median nerve mobilization techniques in the treatment of carpal tunnel syndrome: a systematic review. J Hand Ther; 2017.S0894-1130:30214-4

26. Sucher BM, Hinrichs RN, Welcher RL, Quiroz LD, St Laurent BF, Morrison BJ. Manipulative treatment of carpal tunnel syndrome: biomechanical and osteopathic intervention to increase the length of the transverse carpal ligament: part 2. Effect of sex differences and manipulative "priming". The Journal of the American Osteopathic Association; 2005.105, 135-143.

PubMed: https://www.ncbi.nlm.nih.gov/pubmed/15863733

27. Wolny T, Saulicz E, Linek P, Shacklock M, Mysliwiec A. Efficacy of manual therapy including neurodynamic techniques for the treatment of carpal tunnel syndrome: a randomized controlled trial. J Manipulative Physiol Ther; 2017.40:263-272. DOI: 10.1016/j.jmpt.2017.02.004 